\title{
Au-bearing Pyrite and Pt-Re-rich Molybdenite in the Sulphide Mineralized Younger Granites in the Eastern Desert of Egypt
}

\author{
Mohamed Fahmy Raslan \\ Nuclear Materials Authority, El Maadi, Cairo, Egypt
}

*Corresponding Author: Mohamed Fahmy Raslan, Nuclear Materials Authority, El Maadi, Cairo, Egypt

\begin{abstract}
Several precious and interesting metal values have been determined in pyrite and molybdenite sulphide minerals collected from the younger granite samples of Gattar and El Missikat areas of Egypt. While pyrite can attain about $4 \%$ by weight of El-Missikat rock samples, molybdenite reach about $2.5 \%$ by weight of Gabal Gattar granite. Analytical results indicate that pyrite assays in average 5120 ppm for gold. EMPA analyses revealed that molybdenite assays in average 6900, 1600, 2400 and 1500 ppm for platinum, gold, rhenium and uranium respectively. The obtained data revealed that the detected gold in Gattar pyrite is present mainly as "invisible gold" rather than as submicroscopic or nanoparticles of native gold and occurs within the structure of pyrite most probably incorporated as chemically bond gold. The studied sulphide minerals are of high economic potentiality as a source for several economic precious metal values such as gold, platinum, rhenium and uranium.
\end{abstract}

Keywords: pyrite and molybdenite; precious metals; invisible gold: platinum and rhenium; Eastern Desert; Egypt.

\section{INTRODUCTION}

Several younger granitic plutons in Egypt are found hosting a variety of rare metal mineralization including uranium. Two of these granite plutons; namely El-Missikat and Gattar are located in the central and northern parts of the Eastern Desert respectively. The general geology and radioactivity of both plutons have been studied by several authors (e.g. El-RAMLY and AKAAD 1960; GHOBRIAL and LOTFI 1972; DARDIR and ABU ZEID 1972; AKAAD and NOWEIR 1980; EL-KASSAS and BAKHIT 1989; HUSSEIN and SAYYAH 1992, etc.).

For the purpose of the present study, visible pyrite-rich granite samples were collected from ElMissikat uranium exploratory mine. Also, molybdenite-rich granite samples were collected from Gabal Gattar granitic pluton which represents one of the most important molybdenum mineralized district in Egypt.

Pyrite is actually one of the principal Au-bearing minerals in refractory gold ores and in which gold is often referred to as "invisible" gold. The gold content of arsenian pyrites generally increases with arsenic content. Much of this gold is present as "invisible" gold (particles less than $0.1 \mu \mathrm{m}$ ) and many studies shown that the gold consists either of submicroscopic metallic particles or is incorporated as chemically bond gold (CATHELINEAU et al. 1989; CABRI et al. 1989; COOK and CHRYSSOU LIS1990; and FLEET and MUMIN 1997).

"Invisible gold" in pyrite is defined as an Au solid solution of the pyrite lattice, sub-microscopic Au nanoparticles in the pyrite, or other chemisorption complexes of Au (YUICHI MORISHITS, 2019). The term invisible gold includes (1) nonstructural submicron scale particles ( 0.1 to 0.01 microns) and nanoscale $(\sim 1$ to $10 \mathrm{~nm})$ particles, and (2) structurally bound solid solution or isomorphic states. Because invisible gold is difficult to separate and concentrate from the ores, it has become known as refractory gold. Refractory gold ores are generally far more expensive to process than free gold ores (ROSS R. LARGE, and VALERIY V. MASLENNIKOV, 2020). The detection of invisible gold has become important because, for many countries, high-stock deposits of disseminated sulfide ores with refractory properties are the main source of gold production (A. V. VOLKOV and A. A. SIDOROV, 2017). 
On the other hand, molybdenite has been shown to be the major host phase for Re in many hydrothermal ore deposits (McCANDLESS et al., 1993). Rhenium is generally produced commercially as a by-product of molybdenum from porphyry $\mathrm{Cu}-\mathrm{Mo}$ deposits, since the $\mathrm{Re}$ content of molybdenite in such deposits may be as high as several weight percent (e.g., MELFOS et al., 2001). Rhenium is widely used in the petroleum refining and the electronics industries. It is also applied in modern super-strong high-temperature resistant alloys; micro-admixtures of Re improve the rheological properties of metals such as Mo, W and Ta. Such alloys have application in the construction of spaceships, aircraft and other products designed to be subjected to high temperatures (IVANOV and YUSHKO-ZAKHAROVA, 1989 \& OLGA YU et al., 2019).

The purpose of the present paper is essentially concerned with the preliminary investigation for the mineralogy of the sulphide minerals in both El-Missikat and Gattar plutons as well as determination of their trace elements content. Thus, the studied sulphides were properly investigated using the binocular microscope, the Scanning Electron Microscope as well as the Electron Microprobe.

\section{GEOLOGY AND MinERALIZATON}

Numerous studies (e.g. AKAAD and NOWEIR, 1980 and HASSAN and HASHAD, 1990) have broadly classified the Egyptian granitoids into two main groups: older syn-to late tectonic granite referred to as grey granites (850-650 Ma, subduction-related, I-type granitoids ranging in composition from trondhjemite to granodiorite) and younger or post tectonic granites referred to as pink granite (600-480Ma, of composition ranging between biotite monzogranite and proper granites) HUSSEIN et al. (1982) added third group of alkaline granites which was previously identified with the younger granites. The younger granites (second groups) are falling within the BOWDENS (1985) petrotectonic-time associations of the Pan-African orogeny (i.e. typically equivelant to $\mathrm{A}_{2}$-subtype of EBY, 1992). Rare metal mineralization is particularly and genetically associated with post - orogenic, geochemically distinctive varities of this group of granitic rocks. Since the discovery of vein-type uranium mineralization during early seventies associating El Missikat and El Erediya granitic plutons in the Central Eastern Desert as well as Gattar pluton in the North, these rocks were the subject of intensive programs of exploration and prespection.

\subsection{El Missikat Pluton}

Gabal El Missikat granitic pluton lies at about $85 \mathrm{~km}$ midway between Safaga, on the Red Sea Coast and Qena in the Nile Valley (Fig. 1A). The pluton crops out as an oval shaped mass (12km length and $20 \mathrm{~km}$ width) elongated in N-S direction. It intrudes the older granitoids at the northern and western parts. FULLAGER (1981) reported an age of $568 \mathrm{Ma}$ and 570 Ma for Rie el Garra (the eastern lobe of El Missikat granitic mass, Fig. 1B) and El Erediya granitic mass respectively. Both El Missikat and El Erediya fresh granite exhibit common petrographical characteristics. They are pink to red in color, medium to coarse-grained with typically hypidomorphic texture. They are mainly composed of orthoclase perthite, quartz, plagioclase, micas and opaques as essential minerals. Zircon, apatite, fluorite and Fe-Ti oxides as accessory minerals. Anomalous radioactivity was found to be related to uranium mineralization associating silica veins and veilets filling fractures and shear zones. The mineralized shear zones are trending ENE-WSW to NW-SE at El Missikat and ENE at El Erediya respectively (Fig. 1C and D). Exploratory mining was carried out along the shear zones in El Missikat and El Erediya. A total of about $3829 \mathrm{~m}$ of galleries were excavated in both areas. Uranium mineralization (microbotryoidal pitchblende and secondary uranium minerals) is disseminated in the black and jasperoid silica. Particularly at El Missikat prospect, uranium minerals are always associated with fluorite occurring as veinlets and veins as well as sulphides such as galena, sphalerite, pyrite and chalcopyrite. Sulphide minerals occur either as veinlets, fracture fillings or as disseminations in the granite. Visible pyrite-rich granite samples were recorded and collected from huge amount of dumps excavated from El-Missikat uranium exploratory mine. 


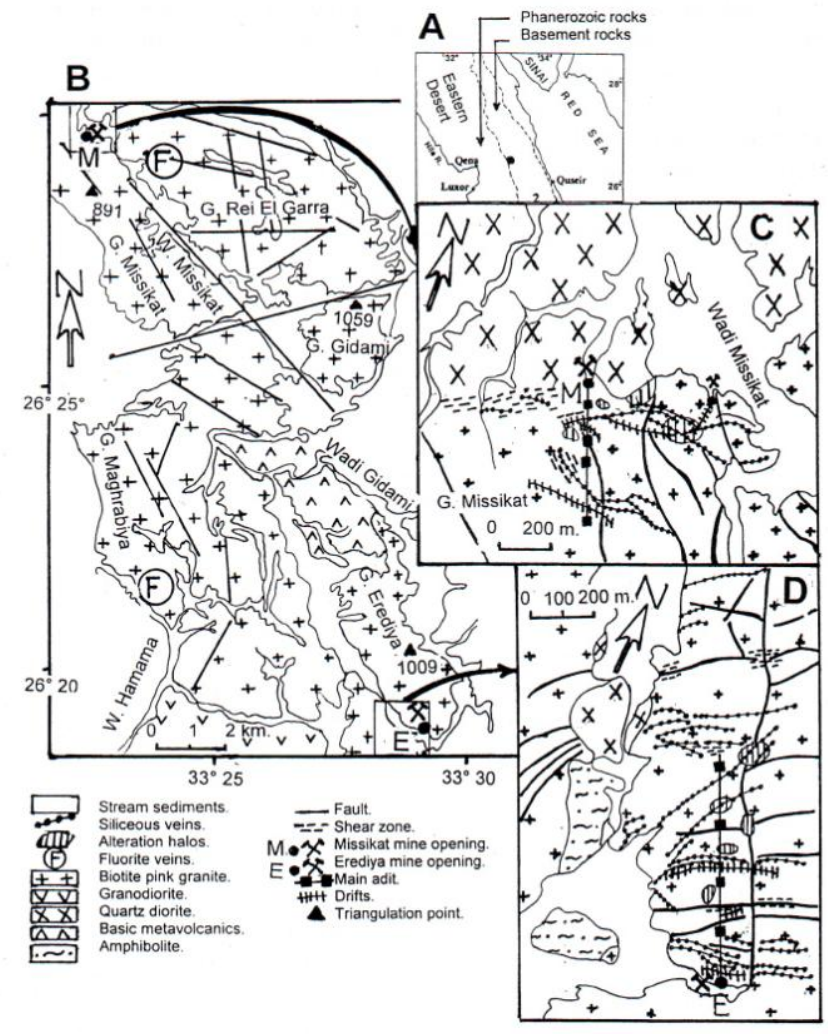

Fig1. A- Location of El Missikat - El Erediya area. B- Geologic Map of El Missikat-El Erediya granitic plutons with areas of Figs $1 C$ and D outlined C-Detailed geologic map of El Missikat Uranium prospect (modified from Abu El Naga, 1993) D-Detailed geologic map of El Erediya Uranium prospect (modified from Rabie et al., 1992).

\subsection{Gattar Pluton}

Four localities of Mo-mineralization were defined and described by DARDIER et al (1983); namely Gebel Gattar, Abu Marwa, Abu Harba and Um Disi (Fig. 2). Gebel Gattar deposit is the largest and its ore reserves were estimated at 2720 tons of metallic Mo. Old mining operations in Gebel Gattar date back to 1925 and comprise a $16 \mathrm{~m}$ deep vertical shaft and two adits (68 and $176 \mathrm{~m}$ ).

Gabal Gattar area is located $40 \mathrm{~km}$ to the west of Hurghada City at the Red Sea Coast, North Eastern Desert (Fig. 3). The geology of the area was previously studied by GHOBRIAL and LOTFI (1967) and EL RAKAIBY and SHALABY (1988). The rock units cropping out at this area are mainly metavolcanics, granodiorite, diorite, Hammamat sediments and younger granites. The granitic rocks of Gattar area are present in two main types; the grey granites are the oldest and the younger pink granites represent the main type prevailing in the area (Fig. 3). Gabal Gattar granites are characterized by the presence of alkali feldspars and quartz in nearly equal amounts, with slight subordinate amounts of plagioclase. The alkali feldspars are mostly orthoclase and microperthite and biotite is slightly altered to biotite. The area as a whole is dissected by a system of dykes mainly trending ENEWSW direction.

The molybdenite ore zone occupies the topmost hills of Gabal Gattar and in the form of a group of thin quartz veinlets. The veinlets thickness ranges from $10 \mathrm{~mm}$ to $20 \mathrm{~mm}$ and the width of the mineralized zone reaches about $25 \mathrm{~m}$, and its length is $500 \mathrm{~m}$. There are four molybdenite ore types present in Gabal Gattar; namely 1- coarse crystalline ore where the molybdenite crystals are distributed irregularly in the quartz veinlets, 2- wall rock ore, the ore is present in the form of a thin film of molybdenite between the ore-bearing quartz veins and the granitic country rocks, 3- ore of thin quartz veinlets and 4- disseminated ore present in the granitic country rock surrounding the Mobearing quartz veinlets (DARDIER et al. 1983). According to HELMY (1999), molybdenite was exploited mainly from quartz veins hosted in potash feldspar-albite-rich muscovite granite. The molybdenite crystals are irregularly distributed and disseminated in quartz veinlets, and mainly concentrated at the contacts with the granitic country rock. 


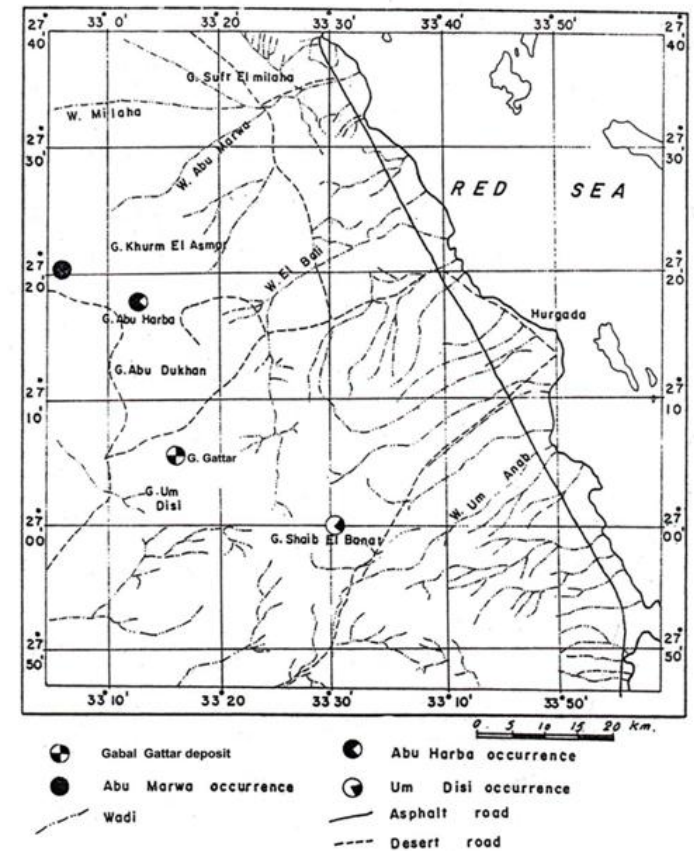

Fig2. Map showing location of the molybdenite deposits in the northern part of the Eastern Desert of Egypt (after Dardir et al. 1983)

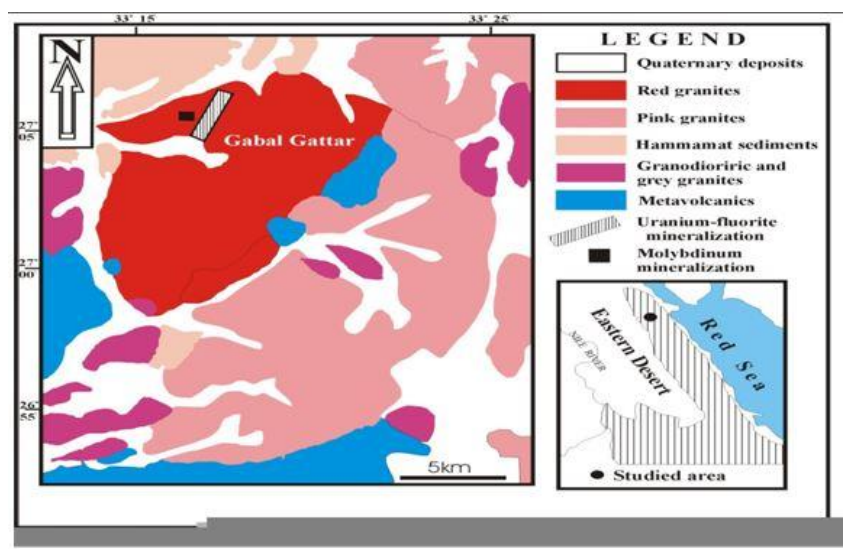

Fig3. Geologic map of G. Gattar area, after Helmy, (1999) slightly modified from El Rakaiby and shalaby, (1988)

\section{Methodolgy}

Representative bulk composite samples from El-Missikat sulphide-rich granite (Fig. 4A) and Gattar molybdenite - rich granite and quartz veins (Fig. 5A) were collected and subjected to crushing, grinding and sieving before heavy minerals separation using bromoform (sp. gr. $=2.85 \mathrm{gm} / \mathrm{cm}^{3}$ ). Some of the picked mineral grains were subjected to the Environmental Scanning Electron Microscope (ESEM). This instrument is supported by energy dispersive spectrometer unit (EDS) model Philips XL 30. The analytical conditions are $30 \mathrm{kv}$ accelerating voltages, 1-2 mm beam diameter and 60-120 second counting time and minimum detectable weight concentration from 0.1 to $1 \mathrm{wt} \%$. All of these analyses were carried out at the laboratories of the Egyptian Nuclear Materials Authority, (NMA).

Thin-polished sections of sulphides were prepared and analyzed using both the Field Emission Scanning Electron Microscope (JEOL 6335F) and the Electron Microprobe (JEOL - Superprobe 733). The former is a cold field emission scanning electron microscope. Cold field emission scopes have the advantage of high brightness (large current density) and small beam diameter (high resolution) at low accelerating voltages to allow imaging of soft polymeric materials without causing sample damage. Resolution of the instrument is around 15 Angstroms depending on the sample. This instrument is fitted with an Oxford Energy Dispersive X-ray Spectrometer (EDS) for elemental analysis of micro areas, a backscattered electron detector that allows compositional analysis, and a cathode 
luminescence detector that can image complex, characteristic-visible spectra for detailed molecular structure information. The applied analytical conditions involved 0.5-to 30 accelerating voltage, 1.5 $\mathrm{nm}($ at $15 \mathrm{KV}$ ) / $5.0 \mathrm{~nm}$ (at 1.0 KV). Mgnification ranged from 10X to 500.000X with digital image up to 2048x 2048 pixels and 1280x 1024 pixels for display image. Imaging modes are secondaery electron imaging (SEI) and backscatter electron imaging (BSI). This instrument that can be available for operation from remote locations can be used for X-ray microanalysis of small areas, lines scans of relative concentrations for multiple elements and for X-ray maps of relative concentrations for multiple elements.

Electron Microprobe used in the present work is a JEOL SUPERPROBE 733 with an accelerating voltage of $15 \mathrm{Kv}$ and a beam size of approximately 1 micron. The crystals used for the elemental analysis involved TAP (Thallium acid phthalate), PET (Pentaerythritol) and LIF (Lithium Fluoride) and the samples were carbon coated (less than 200 angstrom in thickness). The analyzed elements were loaded into the quantitative program (PRZ) and oxygen was made by difference (weight percentage is calculated by subtracting the measured weight). The used standards included Molybdenite (Mo), Rhenium metal (Re), Biotite (Fe), Au metal (Au), Pt metal (Pt), Silver metal (Ag), Crocoite (Pb), Cuprite (Cu), Pentlandite (Ni), Barite (S), Zn metal (Zn) and Uranium metal (U). The preformed EMPA and SEM analyses were carried out during the author fellowship in the Material Science and Engineering Research Center, Major Analytical Instrumentation Center (MAIC) and Particle Engineering Research Center (PERC) respectively, University of Florida, USA.

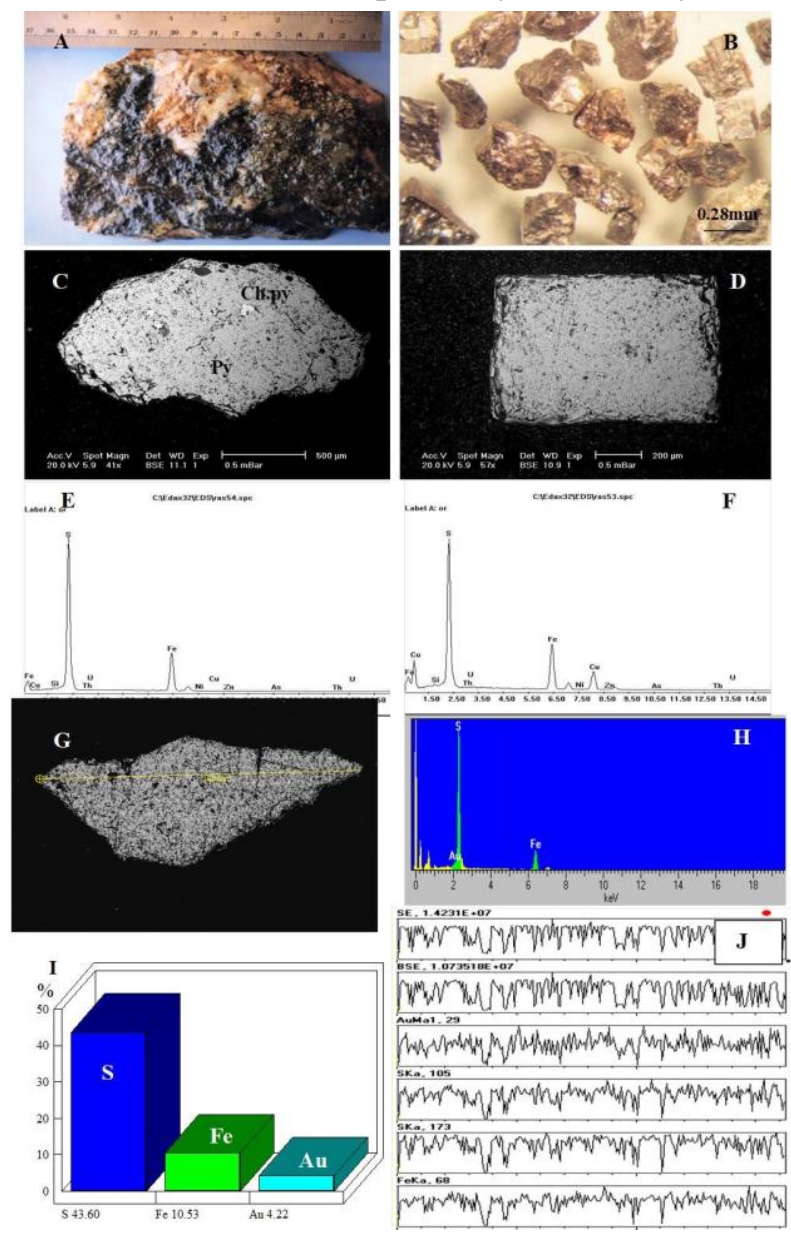

Fig4. A-Close up view of El-Missikat pyrite-rich granite. B-Pyrite grains of brass yellow color, Binocular microscope. $C$ - BSE image of pyrite with chalcopyrite inclusions. D-Microphotograph of cubic pyrite crystal. $E \& F-E D X$ spectra of pyrite and chalcopyrite inclusions respectively. G-Backscattered image showing scan line and microprobe spots within pyrite. H-EDX spectrum of pyrite I-Histogram showing the chemical composition (wt.\%) of pyrite. $J$ - The corresponding scan line results.

\section{Results}

Microscopic examination of the accessory heavy minerals separated from and El-Missikat and Gattar granites revealed that pyrite and molybdenite are the most predominant minerals respectively. Heavy 
minerals investigation of the representative bulk samples of both areas revealed that pyrite and molybdenite can reach about 4 and $2.5 \%$ by weight of the original rock samples respectively. Pyrite occurs as fresh massive subhedral to anhedral opaque grains of brass yellow color and metallic luster (Fig. 4B). Molybdenite grains occur as coarse massive crystals of lead gray color and metallic luster. The crystals are generally manifested in the form of plate-like with minor occurrence of the wire-like shape. They are found to be very malleable and ductile.

\subsection{Gold in Pyrite}

Some of picked pyrite crystals were subjected to semiquantitative analyses using the Environmental Scanning Electron Microscope (ESEM). The obtained SEM data for pyrite (Figs.4 C, D and E) show $\mathrm{S}$ and $\mathrm{Fe}$ as the essential components beside significant amount of $\mathrm{U}$, Th and As (ranging from 0.5 to $2.10 \%)$. Backscattered image for some pyrite grains revealed the presence of numerous chalcopyrite inclusions (Fig.4 F). On using the Field Emission Scanning Electron Microscope (JEOL 6335F), scan line elemental analyses along the crystals revealed that the distribution of gold within the crystals is actually heterogeneous (Figs.4 D and F).

As mentioned above, a JEOL SUPERPROBE 733 was used to determine the chemical composition of the studied sulphide minerals as well as their trace elements content. It was thus revealed that the content of gold in the investigated pyrite ranging from 0.16 to $1.86 \%$ with an average of $0.51 \%$ together with considerable amounts of $\mathrm{Mo}, \mathrm{Pb}, \mathrm{Cu}$ and $\mathrm{Ni}$ (Table. 1).

\subsection{Platinum and Rhenium in Molybdenite}

ESEM data of the investigated molybdenite (Figs. $5 \mathrm{~B}$ and $\mathrm{C}$ ) indicates that the major elements in molybdenite are Mo $(67.00 \%)$ and S (24.40\%) with appreciable amounts of $\operatorname{Re}(1.60 \%), \mathrm{Pt}(1.40 \%)$ and $\mathrm{Au}(1.50 \%)$. On the other hand, the obtained backscattered images from the Field Emission Scanning Electron Microscope (JEOL 6335F) reflect the various habits of the crystals as plat-like or rod-like shape (Figs. $5 \mathrm{D}$ and E). The obtained EDX spectra and scan line along the crystals (Figs. 5 F, G, H and I) revealed the presence of Pt and Re and confirm the heterogeneous distribution of Pt and increasing of Re in the core and margin of the crystal. The scan line data also revealed that the $\mathrm{Re}$ content may increase with the decrease of Mo within the crystal. EMPA analyses revealed that the studied molybdenite contains Pt ranging from 0.24 to $1.77 \%$ with an average of $0.69 \%$ and $\mathrm{Au}$ ranging from 0.44 to 0.54 with an average of 0.16 and Re ranging from 0.08 to $1.23 \%$ with an average of $0.24 \%$ and uranium ranging from 0.10 to $0.46 \%$ with an average of $0.15 \%$ (Table. 1 ).

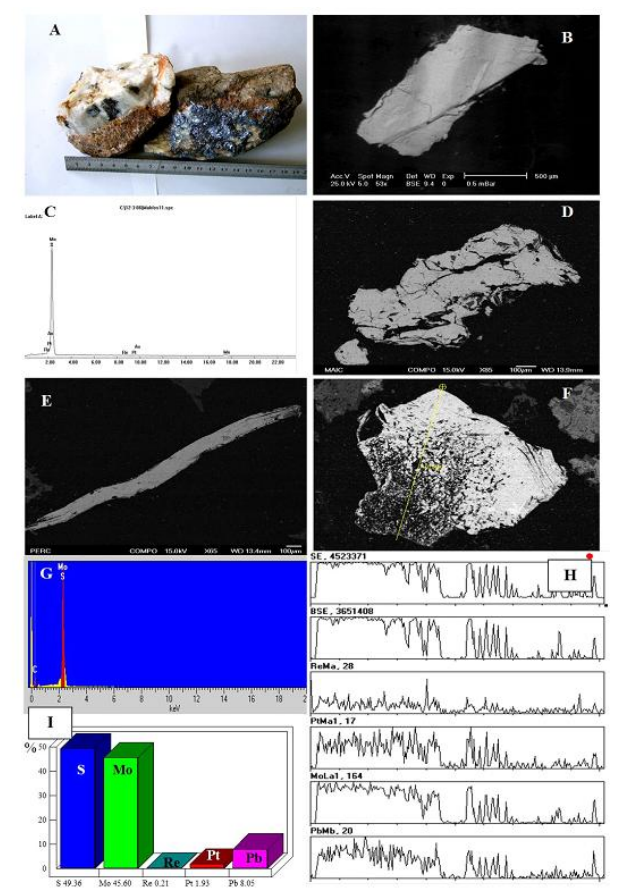

Fig5. A-Close up view of G. Gattarmolybdenite-rich quartz and granite. B\&C-Backscattered electron image of molybdenite crystal and its EDX analyses. D, E and F-BSE microphotographs showing various habits of molybdenite crystals and scan line. G- EDX spectrum of molybdenite. H-The corresponding scan line results IHistogram showing the chemical composition (wt.\%) of the investigated molybdenite. 
Au-bearing Pyrite and Pt-Re-rich Molybdenite in the Sulphide Mineralized Younger Granites in the Eastern Desert of Egypt

Table1. Microprobe analyses of El-Missikat pyrite and GabalGattarmolybdenite crystals from the mineralized younger granites

\begin{tabular}{|c|c|c|c|c|c|c|c|c|c|c|c|}
\hline \multirow{3}{*}{\begin{tabular}{|r|}
$\begin{array}{r}\text { Analyses } \\
(\text { wt } \%)\end{array}$ \\
Elements
\end{tabular}} & \multicolumn{5}{|c|}{ El-Missikat pyrite-rich granite } & \multicolumn{6}{|c|}{ GabalGattarmolybdenite-rich granite } \\
\hline & 1 & 2 & 3 & 4 & 5 & 1 & 2 & 3 & 4 & 5 & 6 \\
\hline & & & & & & & & & & & \\
\hline $\mathrm{U}$ & 0.00 & 0.00 & 0.00 & 0.00 & 0.00 & 0.00 & 0.10 & 0.46 & 0.18 & 0.00 & 0.16 \\
\hline $\mathrm{Fe}$ & 51.16 & 49.19 & 50.99 & 43.93 & 50.84 & 0.08 & 0.15 & 0.00 & 0.12 & 0.00 & 0.00 \\
\hline $\mathrm{Pb}$ & 0.00 & 0.48 & 0.00 & 0.37 & 0.25 & 0.14 & 0.45 & 0.01 & 0.00 & 0.32 & 0.00 \\
\hline S & 15.76 & 15.83 & 18.62 & 15.50 & 18.31 & 14.81 & 15.49 & 10.14 & 14.58 & 15.11 & 14.76 \\
\hline Mo & 0.42 & 0.49 & 0.41 & 0.31 & 0.45 & 47.72 & 50.93 & 37.03 & 47.50 & 48.00 & 49.80 \\
\hline $\mathrm{Re}$ & 0.03 & 0.00 & 0.10 & 0.06 & 0.00 & 0.00 & 1.23 & 0.00 & 0.14 & 0.08 & 0.00 \\
\hline $\mathrm{Cu}$ & 0.00 & 0.42 & 0.05 & 0.12 & 0.05 & 0.00 & 0.08 & 0.06 & 0.03 & 0.14 & 0.01 \\
\hline $\mathrm{Pt}$ & 0.00 & 0.00 & 0.00 & 0.00 & 0.07 & 0.98 & 0.00 & 1.77 & 0.51 & 0.24 & 0.64 \\
\hline $\mathrm{Au}$ & 1.86 & 0.54 & 0.00 & 0.16 & 0.00 & 0.00 & 0.44 & 0.00 & 0.00 & 0.54 & 0.00 \\
\hline $\mathrm{Ni}$ & 0.49 & 0.01 & 0.25 & 0.07 & 0.00 & 0.00 & 0.09 & 0.00 & 0.39 & 0.14 & 0.36 \\
\hline $\mathrm{Zn}$ & 0.01 & 0.00 & 0.00 & 0.00 & 0.00 & 0.37 & 0.03 & 0.49 & 0.04 & 0.00 & 0.00 \\
\hline $\mathrm{Ag}$ & 0.00 & 0.00 & 0.02 & 0.01 & 0.00 & 0.00 & 0.00 & 0.00 & 0.00 & 0.00 & 0.07 \\
\hline
\end{tabular}

\section{DISCUSSION AND CONCLUSION}

Gold is commonly associated with sulphide minerals such as pyrite and arsenopyrite (BOYLE, 1979). Pyrite is actually one of the principal Au-bearing minerals in refractory gold ores and in which gold is often referred to as "invisible" gold. As a matter of fact, significantly high concentrations of gold of $3700 \mathrm{ppm}$ (FLEET and MUMIN 1997) and of up to $9250 \mathrm{ppm}$ (REICH et al. 2005) have been reported in pyrite. It has been assumed that gold deposits on pyrite by precipitation induced by changes in tempreture, pressure, or $\mathrm{pH}$ of the gold-bearing fluid (ROMBERGER, 1988). However, the adsorption-reduction reactions on surfaces are important in accounting for the existence of some gold deposits (BAKKEN et al. 1989; CABRI et al. 1989 and COOK and CHRYSSOULS 1990). Numerous analytical methods have been used to study the chemical state of "invisible gold in sulphide minerals including EMPA analyses. Gold concentration in pyrite is correlated very closely with As concentration and Au usually occurs as micrometer or ultra-micrometer native gold inclusions (MADDOX et al. 1998). Recent spectroscopic and high - resolution electron imaging studies have revealed that the invisible gold occurs within the structure of pyrite and, to a lesser extent , as submicroscopic or nanoparticles of native gold (SIMON et al. 1999, PALENIK et al. 2004, REICH et al. 2005, PAKTUNC et al. 2006 and ROSS R. LARGE, and VALERIY V. MASLENNIKOV, 2020).

Analytical results indicated that the average content of gold in the studied El-Missikat pyrite attains $5120 \mathrm{ppm}$. The obtained data revealed that the detected gold in Gattar pyrite is present mainly as "invisible gold" rather than as submicroscopic or nanoparticles of native gold and most probably incorporated as chemically bond gold due to the following reasons:

1- The distribution of gold within pyrite is actually heterogeneous.

2- The lack of submicroscopic or nanoparticles of native gold in the studied pyrite as indicated from SEM and EMPA analyses.

3- The difficulty to observing and displaying the invisible gold in pyrite grains because of its trace content.

On the other hand, Rhenium is one of the most highly dispersed elements in Earth crust. Rhenium is commonly concentrated in $\mathrm{Cu}-\mathrm{Mo}$ sulfides and tends to be much more abundant in molybdenite than co-existing sulfides. It incorporates Re into its structure at concentrations ranging from some ppb to a few thousand ppm. Major controlling factors of the Re distribution in molybdenite from porphyry $\mathrm{Cu}-$ Mo deposits may be the composition of parent magmas, the concentration of Re in ore-forming fluid and variations of physical and chemical conditions of crystallization (BERZINA et al. 2005).

EMPA analyses revealed that the studied Gattar molybdenite assays 6900, 1600, 2400 and 1500 ppm for platinum, gold, rhenium and uranium respectively. In general, the distribution of the detected metal values is heterogeneous and mainly occurs within the structure of the investigated sulphides. 
It is quite clear that the investigated sulphide minerals contain significant amounts of important metals such as $\mathrm{Au}, \mathrm{Pt}$, and Re. Therefore, further detailed studies should be carried out with the objective of evaluation and determination of the distribution and nature of the recorded metal values in the studied sulphides. The latter is effective in selecting the proper techniques that could be applied for the recovery of these metal values from their refractory ores. It can thus be concluded that the studied sulphide minerals should be considered as a potential source for several economic precious metal values such as gold, platinum, rhenium and uranium

\section{ACKNOWLEDGEMENT}

The preformed EMPA and SEM analyses were carried out during the author fellowship in the Material Science and Engineering Research Center, Major Analytical Instrumentation Center (MAIC) and Particle Engineering Research Center (PERC) respectively, University of Florida, USA. The author sincerely thanks Prof. Dr. Hassan El-Shall Professor of Material Science and Engineering, University of Florida, USA, for his interest as well as for providing EMPA analyses.

\section{REFERENCES}

AKAAD, A. K. \& NOWEIR, A. M. (1980): Geology and lithostratigraphy of the Arabian Desert orogenic belt of Egypt between 2535 and $2630 \mathrm{~N}$. In: Evolution and mineralization of the Arabian - Nubian shield (Convenor: A. M. Al-Shanti), Bull. Inst. Appl. Geol. King Abdulaziz Univ. (Jiddah), 4, 127-136, Pergamon Press, Oxford.

ABU El Naga, H.S.O. (1993) Relation between geology and gammaray spectrometry of El-Missikat radioactiveprospect, Central Eastern Desert, Egypt. M.Sc. Thesis, Ain Shams University.

A. V. VOLKOV \& A. A. SIDOROV (2017): Invisible Gold, Herald of the Russian Academy of Science, Vol. 87 No. 12017

BAKKIN, B.M., HOCHELLA, M.F., MARSHALL, A.F., \& TURNER, A.M. (1989): High-resolution microscopy of gold in unoxidized ore from the Carlin mine, Nevada. Economic Geology, 84, 171-179.

BERZINA, A. N., SOTNIKOV, V. I., ELIOPOULOl M. E. \& ELOPOULOS, D.G. (2005): Distribution of rhenium in molybdenite from porphyry $\mathrm{Cu}-\mathrm{Mo}$ and $\mathrm{Mo}-\mathrm{Cu}$ deposits of Russia (Siberia) and Mongolia. Ore Geology Reviews 26 (2005) 91-113.

BOWDEN, P. (1985): The geochemistry and mineralization of alkaline ring complexes in Africa (a review). J. Afr. Erth Sci., 3, 17-39.

BOYLE, R.W. (1979): The geochemistry of gold and its deposits. Geological Survey of Canada Bulletin, 280.

CABRI, L. J., CHRYSSOULIS, S. L.., DE VILLIERS, J.P.R., LAFLAMME, J.H.G., \& BUSECK, P.R. (1989): The nature of "invisible" gold in arsenopyrite. Canadian Mineralogist, 27, 353-362.

CATHELINEAU, M., BOIRON, M. C., HOLLIGERr, P., MARION, P., \& DENIS, M. (1989): Gold in arsenopyrite: Crystal chemistry, location and state, physical and chemical conditions of deposition. Economic Geology, Monograph 6, 328-341.

COOK, N.J.\& CHRYSSOULIS, S.L. (1990): Concentration of invisible gold in the common sulphides. Canadian Mineralogist, 28, 1-16.

DARDR, A.A., \& ABUZEID, M.K. (1972): Geology of the basement rocks between latitudes $27 \circ 00^{\circ}$ and $27 \circ$ 30 N, Eastern Desert. Annals of G.S.E., Cairo, Egypt. Vol. II, p. 129-159.

DARDR, A.A., \& ABUZEID, M.K. \& GADALLA, S.H.A., (1983): Molybdenite deposits of Gebel Gattar area, Ann. Geol. Surv. Egypt, XIII: 23-37.

EBY, G. N. (1992): Chemical subdivision of the A-type granitoids: petrogenesis and tectonic implications. Geol., 20, 641-644.

EL-KASSAS, I. A. \& BAKHIT, F. S. (1989): Geology of Wadi Atalla - EL-Missikat area, Eastern Desert, Egypt, Qatar Univ. Sci.Bull., 9, 227-224.

EL RAKAIBY, M. L. \& SHALABY, M. H., (1988): Geology of Gebel Gattar batholith, central Eastern Desert, Egypt. M.E.R.C., Ain Shams Univ., 2: 104-115.

EL-RAMLY, M. F\& AKAAD, M. K., (1960): The basement complex in the central Eastern Desert of Egypt between latitudes 2430 and 2540 N Geol. Surv. Egypt, paper No. 8, 35p.

FLEET, M.E. \& MUMIN, A.H. (1997): Gold-bearing arsenian pyrite and marcasite and arsenopyrite from Carlin trend gold deposits and laboratory synthesis. Am. Mineral. 82, 182-193.

FULLAGAR, P. D. (1981): Pan-African age granites of northern Africa: new or reworked sialic materials?. In second symposium on Libyan Geology, London Acad. Press. 
Au-bearing Pyrite and Pt-Re-rich Molybdenite in the Sulphide Mineralized Younger Granites in the Eastern Desert of Egypt

GOBRIAL, M.G. \& LOTFI, M. (1967): The geology of Gebel Gattar and Gebel Dokhan area. General Egyptian organization for geological research and mining, Cairo, Egypt, paper no. 40, $26 \mathrm{p}$.

HASSAN, M. A., \& HASHAD (1990): Precambrian of Egypt. In the Geology of Egypt, (Said, R., ed.). A. A. Balkema, Rotterdam, Bookfield, pp. 201-245.

HELMY, H. M. (1999): Mineralogy, Fluid Inclusions and Geochemistry of the Molybdenum-Uranium-Fluorite Mineralizations, Gebel Gattar Area, Eastern Desert, Egypt, $4^{\text {th }}$ Intern. Conf. On Geochemistry, Alex. Univ. Egypt, 15-16 Sept. pages 171-188.

HUSSEIN, A. A., ALI, M. M. \& EL-RAMLY, M. F. (1982): A proposed new classification of the granites of Egypt. Jour. Volcano. Geotherm. Resear., V.14, p.187-198.

HUSSEIN, H. A. \& SAYYAH, T. A. (1992): Uranium potential of the younger granites of Egypt, Internal. Atomic Energy Agency, Vienna, Austria. 14p

IVANOV, V.V., \& YUSHKO-ZAKHAROVA, O.E., (1989): Rhenium. In: Ivanov, V.V., et al., (Eds.), Siderophile and chalcophile rare metals geological directory. Nedra, Moscow, pp. 425- 459 (in Russian).

MADDOX, L.M., BANCROFT, G.M., SCINI, M.J. \& LORIMER, J.W. (1998): Invisible gold: Comparison of Au deposition on pyrite and arsenopyrite. American Mineralogist, V. 83,pages 1240-1245.

McCANDLESS, T.E., RUIZ, J.R., \& CAMPBELL, A.R., (1993): Rhenium behavior in molybdenite in hypogene and near-surface environments: implications for Re-Os geochronometry. Geochimica et Cosmochimica Acta 57, 889-905.

MELFOS, V., VOUDOURIS, P., ARIKAS, K., \& VAVELIDIS, M., (2001): Rhenium-rich molybdenites in Thracian porphyry CuFMo occurrences, NE Greece. Bulletin of the Geological Society of Greece 34, 1015-1022 (in Greek with English abstract).

OLGA YU. PLOTINSKAYA, VLADIMIR V. SHILOVSKIKH, JENS NAJORKA \& JOHN SPRATT (2019): Grain-scale distribution of molybdenite polytypes versus rhenium contents: $\mu$ XRD and EBSD data. Mineralogical Magazine 83(5):639-644

PAKTUNC, D., KINGSTON, D. \& PRATT, A. (2006): Distribution of gold in pyrite and in products of its transformation resulting from roasting of refractory gold ore. The Canadian Mineral. Vol. 44, pp.213-227.

PALENIK, C.S., UTSONOMIYA, S., REICH, M. KESLER, S.E., WANG, L. \& EWING, R.C. (2004): "Invisible" gold revealed: direct imaging of gold nanoparticles in a Carlin-type deposits. Am. Mineral. 89, 1359-1366.

REICH, M., KESLER, S.E., UTSONOMIYA, S., PALENIK, C.S., \& EWING, R.C. (2005): Solubility of gold in arsenian pyrite. Geochim. Cosmochim. Acta 69, 2781-2796.

RABIE, S.I., SADEK, H.S., \& ABDEL HADI, H.M. (1992): Ground geophysical prospecting for radioactive minerals in El-Erediya prospect, Central Eastern Desert, Egypt. Intern. Rept. Nucl. Mater. Authority, exploration Division, No.6/92.

ROMBERGER, S.B. (1988): Geochemistry of golg in hydrothermal deposits. U.S. Geological Survey Bulletin, 1857-A, A9-A-25.

ROSS R. LARGE, \& VALERITY V. MASLENNIKOV (2020): Invisible Gold Paragenesis and Geochemistry in Pyrite from Orogenic and Sediment-Hosted Gold Deposits, Minerals 2020, 10, 339; doi:10.3390/min10040339.

SIMON, G., HANG, H. PENNER-HAHN, J.E., KESLER, S.E.\& Kao, L.(1999): Oxidation state of gold and arsenic in gold-bearing arsenian pyrite. Am. Mineral. 84, 1071-1079.

YUICHI MORISHITA, NAPOLEON Q. HAMMOUD, KAZUNORI MOMII, RIMI KONAGAYA, YUJI SANO, NAOTO TAKAHATA \& HIROTOMO UENO (2019): Invisible Gold in Pyrite from Epithermal, Banded-Iron-Formation-Hosted, and Sedimentary Gold Deposits: Evidence of Hydrothermal Influence, Minerals J. Minerals 2019, 9, 447; doi:10.3390/min9070447

Citation: Mohamed Fahmy Raslan, (2021) "Au-bearing Pyrite and Pt-Re-rich Molybdenite in the Sulphide Mineralized Younger Granites in the Eastern Desert of Egypt", International Journal of Mining Science (IJMS), 7(1), pp. 1-9. DOI: http://doi. org/10.20431/2454-9460.0701001

Copyright: (C) 2021 Mohamed Fahmy Raslan, This is an open-access article distributed under the terms of the Creative Commons Attribution License, which permits unrestricted use, distribution, and reproduction in any medium, provided the original author and source are credited. 